\title{
Notes on the vocalizations of White-bibbed Babbler (Stachyris thoracica)
}

Peter Boesman

In the following we briefly analyze and compare voice of the two races of White-bibbed Babbler (Stachyris thoracica). We also try to quantify the extent of any vocal differences using the criteria proposed by Tobias et al. (2010), as a support for taxonomic review.

We have made use of sound recordings available on-line from Xeno Canto (XC) and Macaulay Library (ML).

Most diagnostic vocalization is a long churr.

W Java (thoracica)

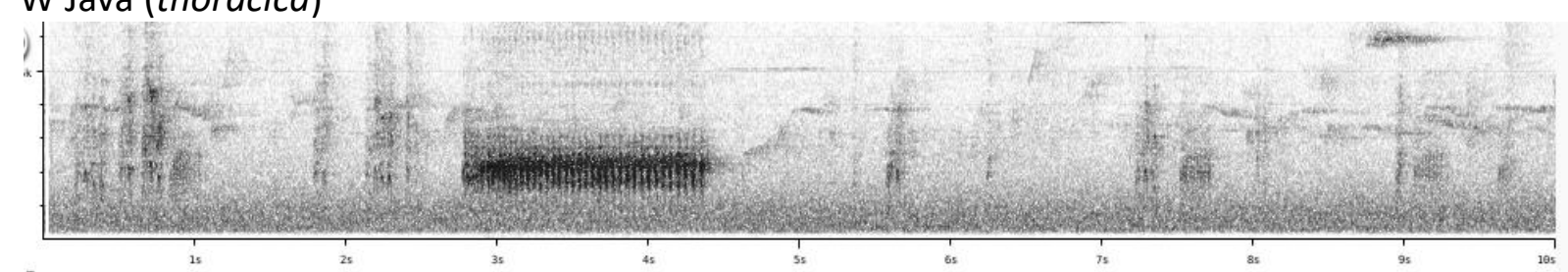

C Java, Mt. Merapi (race orientalis ???)

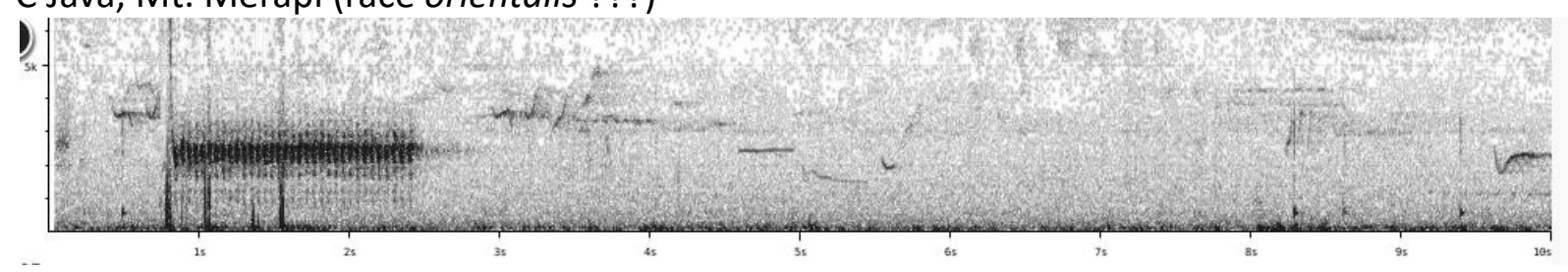

Also shorter rattles:

W Java (thoracica)

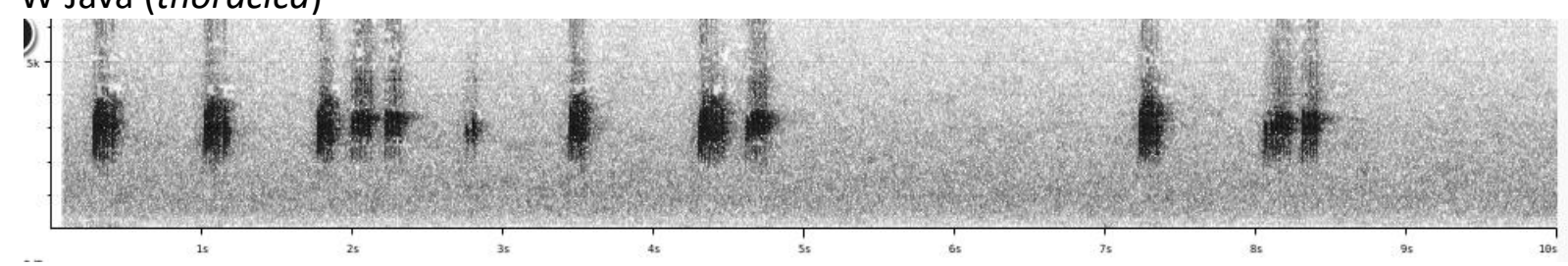

E Java (orientalis)

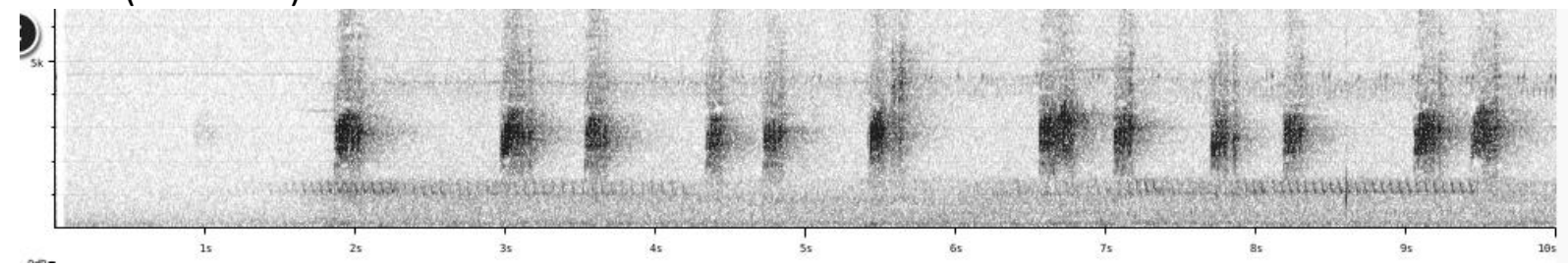

There are few recordings available, especially of race orientalis, but based on present evidence we can only conclude that there are no clear vocal differences. 
This note was finalized on 7th April 2016, using sound recordings available on-line at that moment. We would like to thank in particular the sound recordists who placed their recordings for this species on XC and ML: Heru Cahyono, David Edwards, Frank Lambert, Mike Nelson, Bas van Balen and Arnoud van den Berg.

\section{References}

Tobias, J.A., Seddon, N., Spottiswoode, C.N., Pilgrim, J.D., Fishpool, L.D.C. \& Collar, N.J. (2010). Quantitative criteria for species delimitation. Ibis 152(4): 724-746.

\section{Recommended citation}

Boesman, P. (2016). Notes on the vocalizations of White-bibbed Babbler (Stachyris thoracica). HBW Alive Ornithological Note 265. In: Handbook of the Birds of the World Alive. Lynx Edicions, Barcelona. (retrieved from http://www.hbw.com/node/1251705 on 5 October 2016). 